Beard, R. (2003) 'Not the Whole Story of the National Literacy Strategy: A Response to Dominic Wyse' British Educational Research Journal, 26, 6, 917-928.

\begin{abstract}
There is evidence that the National Literacy Strategy has led to a sustained increase in literacy attainment, especially in reading, although recent international comparisons also suggest some additional issues regarding pupil performance in England. The relative success of the NLS may at least partly lie in the policy application of several complementary areas of educational research, a suggestion disputed by Dominic Wyse (2003). However, his critical commentary is marred by important omissions, particularly of reference to debates about the teaching of reading and to the statutory status of the National Curriculum for English. His alternative suggestions on the use of 'child development' evidence lack methodological detail and are only partly formulated.
\end{abstract}




\section{The National Literacy Strategy and national standards}

Dominic Wyse has raised some interesting questions about the National Literacy Strategy (NLS) and the research base that informed it ['The National Literacy Strategy: A Critical Review of Empirical Evidence', this volume]. As he notes, the NLS and the companion National Numeracy Strategy have been described as the most ambitious large-scale strategy of educational reform witnessed since the 1960s (Fullan, 2000). Further evidence in support of this claim has been published since Wyse's paper was completed. After a period of 30 years when primary school literacy standards in England remained largely unchanged (Brooks, 1998), there is evidence that the NLS has led to a sustained increase in literacy attainment, especially in reading (DfES, 2003). The increase in reading may be reflected in England's rise in international league tables of reading literacy. In the mid-1990s, the performance of England's nine-year-olds was around the international average (Brooks et al., 1996). By 2001, England was ranked third in a study of the reading achievement of ten-yearold pupils (Year 5 in England) in 35 countries (Twist et al., 2003).

At the same time, there are some continuing issues in England's international profile of literacy attainment. Pupil performance in reading for literary purposes remains higher than in reading for informational purposes. Girls continue to perform better than boys (as they do in all countries participating in the 2001 research), although gender differences in England are smaller for better readers and also smaller for all English pupils in reading for informational purposes. English children's attitudes to reading compare less favourably in international comparisons: in England, 44\% expressed highly positive attitudes to reading and $13 \%$ predominantly negative attitudes, compared with the international averages of $51 \%$ and $6 \%$ respectively. Leisure reading seems to have greater competition from other pursuits in 
England, as ten-year-old children tend to play computer games more frequently than their international peers and also watch television more frequently and for longer (ibid.).

Any increase in raising reading standards will reflect the sustained hard work by thousands of teachers and pupils. In relation to the NLS, such an increase also needs to be considered in the light of a substantial increase in investment in primary education by central government, in training materials, in-service programmes and the appointment of several hundred literacy consultants. Complex questions also remain about the reliability of the implementation of the NLS (Reynolds, 1998) and the sustainability of the changes in practice that it has promoted (Earl et al., 2003). Nevertheless, a more profound explanation of the success of the NLS may lie in the policy application of several complementary areas of educational research. The possibility that research has been judiciously applied in ways that have bolstered national attainment - mediated by the promotion of more productive pedagogical approaches - is of particular interest, coming as it does soon after a time when educational research has been subjected to substantial criticisms (e.g. Hargreaves, 1996; Tooley and Darby, 1998; Woodhead, 1998).

\section{As the research predicted?}

The possibility that the success of the NLS might have been predicted from a close reading of research publications in several complementary fields was the focus of a recent chapter (Beard, 2002). As Wyse acknowledges, other published criticisms of the NLS have not always been as measured and scholarly as those that he provides in his article. Nevertheless, his critical commentary is marred in a number of ways, largely by what is omitted from it. 
For instance, much of the content of the chapter in question, which Wyse describes as 'contentious', is not directly referred to in his paper. Neither does Wyse mention several aspects of the NLS Review of Research and Other Related Evidence (Beard, 1999) on which the chapter builds. Such wide-ranging reference is important in contextualising any discussion of the research-practice interface that the NLS represents. As a consequence of these omissions, Wyse does not acknowledge two key parameters of the issues being discussed: (i) the historical perspective of debates about the teaching of reading and (ii) the statutory status of the National Curriculum for English from which the non-statutory NLS Framework for Teaching (FFT) is derived.

\section{The use of a historical perspective (i)}

The use of a historical perspective enables comparisons to be made between the inconclusive initiatives in British literacy education that are discussed in the chapter and the contrast not only with the success of the NLS, but also of its forerunner, the 1996 National Literacy Project (NLP). The evaluation of the NLP by the National Foundation for Educational Research (NFER) using standardised tests on over 7000 pupils in 250 schools revealed highly significant gains in all pupil sub-groups, including ethnic minorities (Sainsbury et al., 1998). The NLP has been described as a 'precipitating' influence on the NLS (Beard, 2000). Similarly, there is no mention in Wyse's article of substantial sections of the NLS Review, including the 'policy and strategic justifications', the 'general model of reading and writing' and evidence related to the 'generic teaching areas'. The paper thus lacks any reference to some of the 'predisposing' influences on the NLS (Beard, 2000), such as the international comparative data on reading literacy attainment referred to above. 
Instead, Wyse discusses only two areas in detail, inspection evidence and school effectiveness evidence. In relation to the former, he argues that 'abrupt changes in recommendations for the teaching of reading and writing accompanied by methodologically weak systems mean that national analyses of inspection evidence are unreliable as sources of evidence to support the teaching methods of the FFT'. Such a bold assertion necessitates careful scrutiny. The sensationalist press headlines during the time of Ofsted's first Chief Inspector notwithstanding, the national survey data from inspection programmes provide a specific source of information on trends in school practices. Discrepancies with research findings have not been as great as Wyse suggests.

\section{Continuity and change in inspection evidence?}

The greatly increased inspection programme since Ofsted supplanted the system led by Her Majesty's Inspectorate (HMI) in 1992 has been the subject of extensive discussion, as in the wide-ranging collection of papers brought together by Cullingford (1999). Of particular concern have been the validity and reliability of inspectors' ratings of teachers and schools, which are then made publicly available. Some commentators also draw a distinction between the ethos of the two systems that 1992 bifurcated. The post-1992 era has been described as a time when schools have been inspected by 'over 14,000 registered, team and lay inspectors in contracting teams, some of whom appear to display the journeyman characteristics of jobbing builders' (Kogan and Maden, 1999, p.26). The pre-1992 era has been described as a time when schools were inspected by the use of the distinctive 'connoisseurship' of HMI (Grubb, 1999), in which HMIs were seen as 'generally benign, supportive and highly skilled in their subject specialism' (Fitz-Gibbon and Stephenson-Forster, 1999, p. 97). It is important to note, though, that the setting up of Ofsted in 1992 did not mean the end of HMI, although the role of the latter was substantially reduced. HMI is still centrally involved in major national 
evaluations and in summarising and reporting the implications of the annual round of data provided by school inspections. Inspection evidence is thus made up of a number of strands, including survey data largely provided by the continuing work of HMI (for example the reports on the evaluation of the NLP and NLS), the annual subject reviews that are written by HMI on the basis of the school inspection programme (which also contribute to the Annual Report of Her Majesty's Chief Inspector) and the inspection reports of individual schools.

The NLS Review drew particularly on the first two of these, concentrating on the recurrent findings from descriptive survey data that are provided and analysed by the long-standing and continuing work of HMI. The survey data have generally confirmed, and added a sense of national proportion to, the findings from other independent research studies. For example, several studies (Cato et al., 1992; Ireson et al., 1995; Wragg et al., 1998;) have subsequently confirmed the lack of shared reading teaching methods identified in the inspection evidence from the first year of the 1989 National Curriculum (HMI, 1991). Shared reading was developed in New Zealand specifically to meet the needs of disadvantaged pupils (Holdaway, 1979,1982 ) and has been a central element of catch-up programmes in the USA and Australia (Slavin, 1996; Crevola and Hill, 1998) but its use in the UK has appeared to have been limited until it became a central part of the NLP/NLS.

An exception to this congruence between research and inspection evidence can be found in the debate that arose in relation to the 1996 Ofsted report on The teaching of reading in 45 Inner London primary schools. As the NLS Review notes, a critique by Mortimore and Goldstein (nd) focused on the attribution of effectiveness to schools without using an appropriate longitudinal design. However, the basic findings of the survey of teaching approaches used in the 45 schools were not subjected to the same level of criticism. 


\section{The special case of phonics}

Wyse is particularly concerned that the tone of inspection evidence may have changed in the mid-1990s in relation to the teaching of phonics. Again, though, a historical perspective provides important additional information about the evolving knowledge base of that time. The use of this knowledge base in the revision of the National Curriculum had in turn considerable implications for curriculum provision and thus inspection focus.

In the late 1980s and early 1990s, the need for policy to address the relationship between the knowledge base and classroom practice was indicated by a succession of reports from the NFER (Gorman, 1989; Brooks et al., 1992; Beard and Oakhill, 1994). These suggested that teacher education was being excessively influenced by an 'orthodoxy' that was assumed in several of the most recommended books on ITT booklists. By 1992, a booklet reflecting the orthodoxy (Waterland, 1985, 1988) was the most recommended text on booklists for reading courses in initial teacher education in England, Wales and Northern Ireland (Brooks, et al., 1992). The orthodoxy centred on the use of 'real' (individual) books for the teaching of early reading, rather than the use of purpose-written schemes or programmes. The underlying ideas were laudably concerned with the improvement in the quality of early reading material. They were also linked to more questionable assumptions.

Firstly, it was assumed that the learning of written language was psychologically similar to the learning of a first language. Secondly, reading was characterised as a process of predicting sequences of language, with an emphasis on checking predictions, particularly through first letter cues. Thirdly, phonics was described as 'a small part of reading' (Waterland, 1988, p.35). Given Wyse's concern that peer-reviewed research outcomes should be used to 
influence policy and practice, it is noteworthy that Waterland's work was apparently based on an in-service BEd study and was not subjected to peer review. This did not prevent the substantial dissemination of the author's ideas to practising teachers. In the second edition of the booklet, the author reports speaking to 'thousands of teachers' in teacher education events in different parts of the country (Waterland, 1988, p. 9). However, a great deal of evidence has been put forward in support of views that are very different from those that underlay the influential ideas of the late 1980s.

In relation to the comparisons between written and spoken language, Donaldson (1993) has drawn attention to the fact that Vygotsky took a very different view. In comparing what he called 'oral speech' and 'written speech', Vygosky argued that written speech is a separate linguistic function, differing from oral speech in both structure and mode of functioning (Vygotsky, 1962, pp. 180-1). Secondly, in relation to the nature of fluent reading, recent research-based models of fluent reading suggest that reading involves the use of sources of contextual, comprehension, visual and phonological information which are simultaneously interactive, issuing and accommodating to and from each other (see Stanovich, 2000, for a recent overview). The contrasts with the influential ideas of the 1980s has been noted in several independent reviews of research evidence (Beard, 1999; Hurry, 2000; Harrison, 2002).

Thirdly, and most importantly in responding to Wyse's argument, the conclusions from a major review of research on Beginning to Read that was published in the USA (Adams, 1990) indicated the importance of phonic knowledge in early literacy development. In a discussion of peer-reviewed publications whose list numbered over 35 pages, Adams concluded that teaching approaches in which systematic code instruction is included along with the reading 
and writing of meaningful text results in superior reading achievement overall, both for 'lowreadiness' and better prepared pupils (see also Adams, 1993).

\section{The implications of the revised National Curriculum}

Nevertheless, the first version of the National Curriculum for English seemed clearly influenced by the orthodoxy of the late 1980s. In document of 43 pages, phonics was only mentioned once: 'Pupils should be able to...use picture and context cues, words recognised on sight and phonic cues in reading' (DES, 1989, p.7). For reasons that were not clear, the committee that drew up the first version of the National Curriculum for English seemed to overlook substantial psychological research on the phonological aspects of reading, such as the work at the University of Oxford that had been going on for several years (e.g. Bradley and Bryant, 1983).

The National Curriculum was revised for implementation in 1995. In the revised version, 'key skills' for reading in the 5-7 year age-range were spelled out in far greater detail and described as phonic knowledge, graphic knowledge, word recognition, grammatical knowledge and contextual understanding (DfE, 1995, pp. 6-7). The contrast between the 1989 and the 1995 versions of the National Curriculum, and the theories that had appeared to influence the former, raised the issue of how securely primary teachers were placed to teach the revised Curriculum of 1995 . This is not to suggest that phonics teaching was not being undertaken. Rather, lacking the endorsement of the National Curriculum and influential theories of the time, provision may have lacked conviction.

Wyse is not convinced by the comments made in a recent report on Teaching of Phonics, based on successive visits by HMI to a national sample of 300 schools. The report suggests 
that the debate in England is 'no longer about whether phonic knowledge and skills should be taught, but how best to teach them' (Ofsted, 2001, p.1), adding that, before the revision to the National Curriculum and the introduction of the National Literacy Strategy, 'phonics was often taught surreptitiously because teachers felt that their approach to teaching reading lacked official approval: teaching phonics was certainly not the norm' (Ofsted, 2001, p.2). A different view from that expressed by Wyse is that, given the influence of the 1980s orthodoxy and the parsimonious mention of phonics in the first version of the National Curriculum, this state of affairs was hardly surprising.

\section{The use of inspection evidence to support recommendations for practice}

Wyse's article raises questions about the use of inspection evidence in educational publications in general. Substantial reductions in references to inspection evidence would provide dilemmas for those who write in teacher education. For example, one recently published book bases its argument for 'planning for talk' on the following generalisation: 'Ofsted's summary of inspection findings from 1994-1998 clearly states that good literacy teaching needs focused English work outside the structure of the literacy hour'. These words are followed by a direct quotation from the Ofsted report in question. This argument might be seen as another use of 'methodologically weak systems ....in national analyses of inspection [which] are unreliable as sources of evidence to support teaching methods'. Yet this prescriptive use of an Ofsted report is taken from another publication by Dominic Wyse (Wyse and Jones, 2001, p.202). It is not clear how his critique of the use of inspection evidence in the NLS Review of Research and Other Related Evidence is consistent with this use of inspection evidence to support his own recommendations for practice. 


\section{School effectiveness research}

Wyse is also critical of the use of school effectiveness (SE) research in the NLS. Again, though, a re-reading of the FLS Review reveals omissions in the way his article discusses this research. The FLS Review draws on the work of Scheerens (1992) and Creemers (1994) who are acknowledged as key generic influences by the Literacy Task Force (LTF, 1997b, p. 14) that drew up the NLS. The Review makes specific reference to six aspects of 'structured teaching' and to the notion of 'effective learning time', all of which have 'multiple empirical research confirmation' in studies of effective schools, according to Scheerens. Wyse instead focuses on another aspect of SE, 'opportunities to learn' which, although important, according to Scheerens has only a 'reasonable empirical base'. Wyse only links his discussion of an objectives-based approach to the notion of 'opportunities to learn', which he erroneously reports is used in the Review to 'support' the use of an objectives approach. This is inaccurate. The NLS Review cites this aspect of SE as follows: 'The NLS ....draws directly on the National Curriculum in the content of the Framework and assists [my italics] the related 'opportunities to learn' by adopting a clear objectives-based approach for each primary school term (Beard, 1999, pp. 17-18). At this point in the Review the focus was on the pragmatic aspects of adopting an objectives-based approach, not on its justification.

Wyse seems to have overlooked Scheerens' original words on this issue: 'The general principle of structured teaching is the use of multiple didactic interventions to support the learning process. Examples of this include: making it clear what has to be learnt (formulating learning objectives)...' (Scheerens, 1992, p.83). Neither does Wyse mention Creemers' conclusions that the factors with 'strong empirical evidence' as characteristics of effective teaching include curriculum explicitness and ordering of goals and content. Perhaps the most surprising omission on the topic of objectives, though, is any mention of the fundamental 
work of Tyler (1949) and the development of objectives theory through the work of Madaus and Stufflebeam (1989). These sources discuss the importance of arriving at educational objectives on the basis of considered judgement, taking account of the demands of society, the characteristics of pupils, the potential contributions which various fields of learning may make, the social and educational philosophy of the school and what is known about the attainability of the various types of objectives.

\section{The use of a historical perspective (ii)}

At the same time, the use of teaching objectives in the NLS Framework for Teaching was not simply based on the kind of a priori decision that Wyse seems to assume. The NLS was created by the work of a Literacy Task Force (LTF) in 1996-7 that took into account existing practices. The section in the Preliminary Report on 'The Teaching of Reading: what works' is followed by reference to the National Literacy Project (NLP) that had been set up in the final year of the 1992-97 government (LTF, 1997a). The NLP had been developed in a sample of LEAs under the leadership of a senior member of HMI, John Stannard. In a 1997 paper Stannard reports how the programme of objectives in the NLP Framework for Teaching was to help teachers to shift the emphasis of their planning from what they should be teaching to a more focused concentration on the how [original italics]. A revised form of this Framework was later to be become a central component of the NLS.

The LTF Preliminary Report notes that the NLP appeared to have a sound basis in evidence of 'what works' and goes on to suggest that the work of the NLP seemed likely to make a major contribution to literacy education: 'There is nothing to be gained from a new government coming in and overturning good work which is already in progress. On the contrary, the National Literacy Project provides a helpful beginning from which we can 
develop our Strategy'(LTF, 1997a, p. 20). According to HMI, the highly significant gains in reading attainment reported in the NFER evaluation of the NLP (discussed above) were accompanied by positive response: 'The structure of the hour and the detailed Framework, with its term-by-term objectives, have been well received by teachers' (Ofsted, 1998, p. 4).

\section{The School Matters findings}

Wyse also notes that, in Mortimore et al.'s (1988a) School Matters research, teachers hearing pupils read individually (which he sees as being 'deprioritised' by the NLS) was linked to greater progress in writing. But he fails to note that alternatives to hearing individuals read, for example in shared and guided approaches, were not widely used at the time of research (they do not appear to be mentioned by Mortimore et al.). The paper also omits to mention evidence reported by Harrison (1999) in a review of reading research in the United Kingdom. Harrison reports that, when teachers concentrate their teaching on hearing individual children read, other children may spend up to a third of their time off task. In addition, Wyse is not correct to assert that the NLS did not recognise the importance of individual approaches to the reading of stories. The NLS FFT suggests that the shared and guided reading of the literacy hour may be accompanied by reading to the class, pupils' own independent reading for interest and pleasure, and extended writing (DfEE, 1998, p. 14).

What is more, Wyse does not note in his discussion of Mortimore et al.'s study that some of their findings on school effectiveness are similar to several features of the subsequent NLS. These include structured sessions, a teacher-organised framework but one that also allows pupils to exercise a degree of independence, the use of 'audits' of what has been achieved, a limited focus in sessions, intellectually challenging teaching, maximum communication between teachers and pupils and a work-centred environment. 
Wyse's critique of SE research also fails to note the cautions about the limitations of school effectiveness research referred to in the NLS Review (Beard, 1999, pp. 16-17). Researchers have consistently stated that the outcomes from their research are inappropriate for the production of 'blue-print' schools and practices. Instead, SE findings, and the meta-analyses that are often used, provide a sense of direction for school improvement, especially in the light of a core of findings from a variety of studies in several different countries (see Mortimore, 1991; Davies, 2000; Goldstein and Woodhouse, 2000; and Reynolds and Teddlie, 2001, for a discussion of some key issues).

Wyse appears to be unconvinced about relationship between school effectiveness research and reading. But he does not acknowledge how, according to SE research, once pupils begin school, the school itself can have a significantly greater influence on pupil progress than social factors (Sammons, Hillmore and Mortimore, 1995, p. 6). In relation to reading progress, this 'value added' by the school can be four times more important than background factors such as age, gender and social class (Mortimore et al., 1988a and b). For reading, the differential effectiveness (value added) of individual schools has been found to be greatest for pupils with low initial attainment (Sammons et al., 1993). Furthermore, the long-term influence of positive primary school factors on subsequent GCSE attainment has been indicated in a follow up to the 1988 study by Mortimore et al. (Sammons, Nuttall, Cuttance and Thomas, 1995).

\section{'Child Development'}

There is only space to deal briefly with the final section of Wyse's article, on 'Child Development' studies. This is a welcome attempt to provide an alternative to the NLS. 
Despite the publication of various cautions and criticisms, the NLS has not yet been challenged by other research-based curriculum models for literacy education that could be adopted with similar or greater likelihood of success on a national scale. This is surprising as the NLS only has 'guidance' status. It recommends that every primary school should adopt the Framework for Teaching unless the school can demonstrate through its action plan, schemes of work and test performance that its own approach is at least as effective. If or when alternative models are provided, though, a key variable will be the statutory content of the NC for English, something that Wyse does not appear directly to address.

Again, though, what is put forward in Wyse's paper has some important weaknesses. Firstly, a number of important elements in the relevant literature are missing. For example, some large-scale development studies are not included, some of which have been published in this journal (e.g. Blatchford et al, 1987; Tizard et al, 1988; Blatchford and Plewis, 1990; Blatchford, 1991).

The critique of the phonics details of the FFT seem not to take into account the implications of the substantial research reviews that have been undertaken in recent years (e.g. Adams, 1990; Kamil et al. 1999; and National Reading Panel, 2000). Similarly, the criticism of the 'range' sections of the FFT needs to be further compared with the statutory requirements of the National Curriculum.

There is also criticism of the distinctions between 'word', 'sentence' and 'text' levels, but Wyse appears to overlook that the sub-division is common in linguistic description and appears in the writings of Perera, whose work he apparently draws upon. Similarly, having apparently implied that there should be a return to individualised teaching approaches in place 
of shared and guided approaches, the paper paradoxically draws upon the work of the Centre for Language in Primary Education which has in fact been in the vanguard of the promotion of shared reading and writing (CLPE, 1990). The paper goes on to propose an integration of the word and sentence level without any theoretical or linguistic justification.

Secondly, the amendments to the NLS that are put forward lack rationale and are only partly formulated. The paper announces an analysis of research evidence of 'language and literacy development', yet the various studies listed comprise a mix of individual case studies, longitudinal research involving large samples, conceptual frameworks and intuitive theories. There is no discussion of the methodological issues involved in integrating such diverse sources. Nor are any details given of the 'analysis and synthesis' that led to the identification of 'six stages of reading and writing benchmarks'. As it is, this section of the paper appears to be little more than a preliminary listing of a few interesting ideas. It needs a considerable amount of further work, including reference to the relevant psychological and linguistic studies, such as the models of Frith (1985) and Ehri (1997) to establish the appropriate level of validity. Moreover, it is not always clear that the same degree of criticality is applied to all the sources that are discussed, compared with the searching critique that is mounted on the NLS-related evidence For instance, the paper goes on to suggest greater use of 'process writing' without any mention of the various cautions put forward by Smagorinsky, (1987); White (1991); Gilbert (1989); Czerniewska (1994) and Lensmire (1994).

Having criticised the use of objectives in the NLS, however, the final sections of the article then appear to continue working with them. After the challenge to various aspects of the NLS evidence base, the article concedes that the NLS as a whole will probably have an overall positive impact on raising achievement. Such conclusions seem to contradict the earlier 
suggestion that claims of research findings predicting the success of the NLS were 'contentious'. It is curious why the rest of the article is so reluctant to accept that research applications may be making a difference to pupil attainment. 


\section{REFERENCES}

ADAMS, M.J. (1990) Beginning to Read: Thinking and Learning about Print (Cambridge, Mass., MIT Press).

ADAMS, M.J. (1993) Beginning to Read: An overview, in: R. Beard (Ed) Teaching Literacy: Balancing Perspectives (London, Hodder \& Stoughton).

BEARD, R. (1999) The National Literacy Strategy: Review of Research and Other Related Evidence (London, Department for Education and Employment).

BEARD, R. (2000) Research and the National Literacy Strategy, Oxford Review of Education, 26, pp. 421-436.

BEARD, R. (2002) As the research predicted?: Examining the success of the National Literacy Strategy', in: R. Fisher, M. Lewis, \& G. Brooks (Eds) Raising Standards in Literacy (London, Routledge).

BEARD, R. (2003) Breadth, balance and the literacy hour, Primary History, 34, pp. 9-11

BEARD, R. \& OAKHILL, J. (1994) Reading by apprenticeship? A Critique of the apprenticeship approach to the teaching of reading (Slough, National Foundation for Educational Research).

BLATCHFORD, P. (1991) Children's handwriting at 7 years: Associations with handwriting on school entry and pre-school factors, British Journal of Educational Psychology, pp. 73-84. 
BLATCHFORD, P., BURKE, J., FARQUHAR, C., PLEWIS, I. \& TIZARD, B. (1987)

Associations between pre-school reading related skills and later reading achievement, British Educational Research Journal, 13, pp. 15-23.

BLATCHFORD, P. \& PLEWIS, I. (1990) Pre-school reading-related skills and later reading achievement: further evidence, British Educational Research Journal, 16, pp. 425-428.

BRADLEY, L. \& BRYANT, P. (1983) Categorising sounds and learning to read: a causal connection, Nature, 301, pp. 419-421.

BROOKS, G. (1998) Trends in standards of literacy in the United Kingdom, 1948-1996, Topic, 19, 1-10.

BROOKS, G., GORMAN, T., KENDALL, L. \& TATE, A. (1992) What Teachers in Training are Taught about Reading (Slough, National Foundation for Educational Research).

BROOKS, G., PUGH, A.K. \& SCHAGEN, I. (1996) Reading Performance at Nine (Slough, National Foundation for Educational Research).

CATO, V., FERNANDES, C., GORMAN, T., KISPAL, A. with WHITE, J. (1992) The Teaching of Initial Literacy: How do teachers do it? (Slough, National Foundation for Educational Research).

CENTRE FOR LANGUAGE IN PRIMARY EDUCATION (1990) Shared Reading Shared Writing (London, Inner London Education Authority/CLPE).

CREEMERS, B.P.M. (1994) The Effective Classroom (London, Cassell). 
CREVOLA, C.A. \& HILL, P.W. (1998) Evaluation of a whole-school approach to prevention and intervention in early literacy, Journal of Education for Students Placed At Risk, 3, pp. 133-157.

CULLINGFORD, C. (Ed) (1999) An Inspector Calls (London, Kogan Page).

CZERNIEWSKA, P. (1994) Writing: Process approach to teaching in: R.E. Asher (Ed) The Encyclopaedia of Language and Linguistics 9, 5047-49 (Oxford, Pergamon Press \& the University of Aberdeen).

DAVIES, P. (2000) The relevance of systematic reviews to educational policy and practice, Oxford Review of Education 26, pp. 365-378.

DEPARTMENT OF EDUCATION \& SCIENCE (1989) English in the National Curriculum (London, Her Majesty’s Stationery Office).

DEPARTMENT FOR EDUCATION (1995) English in the National Curriculum. (London: Her Majesty’s Stationery Office).

DEPARTMENT FOR EDUCATION \& EMPLOYMENT (1998) The National Literacy Strategy: Framework for Teaching (London, DfEE).

DEPARTMENT FOR EDUCATION \& SKILLS (2003) Excellence and Enjoyment: A strategy for primary schools (London, DfES)

DONALDSON, M. (1993) Sense and sensibility: some thoughts on the teaching of literacy', in: R. Beard (Ed) Teaching Literacy: Balancing perspectives (London, Hodder \& Stoughton). EARL, L., WATSON, N., LEVIN, B., LEITHWOOD, K., FULLAN, M. \& TORRANCE, N. with JANTZI, D., MASCALL, B. and VOLANTE, L. (2003). Watching and Learning 3: 
Final report of the external evaluation of England's National Literacy and Numeracy

Strategies (London, Department for Education and Skills).

EHRI, L.C. (1997) Learning to read and learning to spell are one and the same, almost, in:

C.A PERFETTI, L. RIEBEN \& M. FAYOL (Eds) Learning to Spell: Research, theory and practice across languages (Mahwah, N.J., Lawrence Erlbaum).

FITZ-GIBBON, C.T. \& STEPHENSON-FORSTER, N.J. (1999) Is Ofsted Helpful? in: C.

CULLINGFORD (Ed) An Inspector Calls (London, Kogan Page).

FRITH, U. (1985) Beneath the surface of developmental dyslexia, in: K,E. Patterson, J.C. Marshall, \& M. Coltheart (Eds) Surface Dyslexia (Hillsdale, N.J., Lawrence Erlbaum).

FULLAN, M. (2000) The return of large-scale reform, Journal of Educational Change 1, 528.

GILBERT, P. (1989) Student text as pedagogical text, in: S. de Castell, A. Luke \& C. Luke (Eds) Language, Authority and Criticism (London, Falmer Press).

GOLDSTEIN, H. \& WOODHOUSE, G. (2000) School effectiveness research and education policy, Oxford Review of Education 26, pp. 353-363.

GORMAN, T. (1989) What Teachers in Training Read About Reading (Occasional Paper No.

4) (Slough, National Foundation for Education Research).

GRUBB, W.N. (1999) Improvement or control? A US view of English inspection, in: C.

CULLINGFORD (Ed) An Inspector Calls (London, Kogan Page).

HARGREAVES, D. H. (1996) Teaching as a Research-based Profession: possibilities and prospects (London, Teacher Training Agency). 
HARRISON, C. (1999) Reading research in the United Kingdom, in: M.L. KAMIL, P.B. MOSENTHAL, P.D. PEARSON \& R. BARR (Eds) Handbook of Reading Research (Hillsdale, N.J., Lawrence Erlbaum).

HARRISON, C. (2002) The National Strategy for English at Key Stage 3: Roots and Research (London, Department for Education and Skills).

HER MAJESTY'S INSPECTORATE (1991) English Key Stage 1: A report by HM Inspectorate on the first year, 1989-90 (London, Her Majesty's Stationery Office).

HOLDAWAY, D. (1979) The Foundations of Literacy. (Sydney, Ashton Scholastic).

HOLDAWAY, D. (1982) Shared book experience: Teaching reading using favourite books', Theory into Practice, 21, pp. 293-300.

HURRY, J. (2000) Intervention Strategies to Support pupils with Difficulties in Literacy during Key Stage 1: Review of research (London, Qualification and Curriculum Authority).

IRESON, J., BLATCHFORD, P. \& JOSCELYNE, T. (1995) What do teachers do? Classroom activities in the initial teaching of reading, Educational Psychology, 15, pp. 245256.

KAMIL, M.L., MOSENTHAL, P.B., PEARSON, P.D. \& BARR, R. (Eds) (1999) Handbook of Reading Research (Hillsdale, N.J., Lawrence Erlbaum).

KOGAN, M. \& MADEN, M. (1999) An evaluation of evaluators: the Ofsted system of school inspection, in: C. CULLINGFORD (Ed) An Inspector Calls (London, Kogan Page).

LENSMIRE, T. (1994) When Children Write: Critical re-visions of the writing workshop (New York, Teachers College Press). 
LITERACY TASK FORCE (1997a) A Reading Revolution: How we can teach every child to read well (London, The Literacy Task Force c/o University of London: Institute of Education).

LITERACY TASK FORCE (1997b) The Implementation of the National Literacy Strategy. (London, Department for Education and Employment).

MADAUS, G.F. \& STUFFLEBEAM, D.L. (Eds) (1989) Educational Evaluation: Classic works of Ralph W. Tyler (Boston, Kluwer Academic Publishers).

MORTIMORE, P. (1991) The nature and findings of school effectiveness research in the primary sector in: S. Riddell \& S. Brown (Eds) School Effectiveness Research: Its messages for school improvement (London, Her Majesty’s Stationery Office)

MORTIMORE, P. \& GOLDSTEIN, H. (no date) The Teaching of Reading in 45 Inner London Primary Schools: a critical examination of OFSTED evidence (mimeo).

MORTIMORE, P., SAMMONS, P., STOLL, L., LEWIS, D. \& ECOB, R. (1988a) School Matters: The junior years (Wells, Open Books).

MORTIMORE, P., SAMMONS, P., STOLL, L., LEWIS, D. \& ECOB, R. (1988b) The effects of school membership on pupils' outcomes', Research Papers in Education, 3, pp. 326.

NATIONAL READING PANEL (2000) Teaching Children to Read: An evidence-based assessment of the scientific research literature on reading and its implications for reading instruction (Washington, D. C., National Institute for Child Health and Human Development). 
OFFICE FOR STANDARDS IN EDUCATION (1996) The Teaching of Reading in 45 Inner London Primary Schools: A report by Her Majesty's Inspectors in collaboration with the LEAs of Islington, Southwark and Tower Hamlets (London, Ofsted).

OFFICE FOR STANDARDS IN EDUCATION (1998) The National Literacy Project: An HMI evaluation (London, Ofsted).

OFFICE FOR STANDARDS IN EDUCATION (2001) Teaching of Phonics: A paper by $H M I$ (London, Ofsted).

REYNOLDS, D. (1998) Schooling for literacy: a review of research on teacher effectiveness and school effectiveness and its implications for contemporary educational policies, Educational Review, 50, pp. 147-162.

REYNOLDS, D AND TEDDLIE, C (2001) Reflections on the critics, and beyond them, School Effectiveness and School Improvement, 12, pp. 99-113.

SAINSBURY, M., SCHAGEN, I., WHETTON, C., with HAGUES, N. \& MINNIS, M. (1998) Evaluation of the National Literacy Strategy: Cohort 1, 1996-1998 (Slough, National Foundation for Educational Research).

SAMMONS, P., HILLMAN, J. \& MORTIMORE, P. (1995) Key Characteristics of Effective Schools: A review of school effectiveness research (London, Ofsted).

SAMMONS, P., NUTTALL, D. \& CUTTANCE, P. (1993) Differential school effectiveness: results from a reanalysis of the Inner London Education Authority's Junior School Project data, British Educational Research Journal, 19, pp.381-405. 
SAMMONS, P., NUTTALL, D., CUTTANCE, P. \& THOMAS, S. (1995) Continuity of school effects: A longitudinal analysis of primary and secondary school effects on GCSE performance, School Effectiveness and School Improvement, 6, pp. 285-307.

SCHEERENS, J. (1992) Effective Schooling: Research, Theory and Practice (London, Cassell).

SLAVIN, R.E. (1996) Education for All (Lisse, Swets and Zeitlinger).

SMAGORINSKY, P. (1987) Graves Revisited: A look at the methods and conclusions of the New Hampshire study, Written Communication, 4, pp. 331-342.

STANNARD, J. (1997) Raising Standards Through the National Literacy Project (London: Paper presented at the Literacy Task Force Conference, 27.2.97).

STANOVICH, K.E. (2000) Progress in Understanding Reading (New York, Guilford).

TIZARD, B., BLATCHFORD, P., BURKE, J., FARQUHAR, C. \& PLEWIS, I. (1988)

Young Children at School in the Inner City (London, Lawrence Erlbaum).

TOOLEY, J. \& DARBY, D. (1998) Educational Research: A Critique (London, Ofsted).

TWIST. L., SAINSBURY, M., WOODTHORPE, A. \& WHETTON, C. (2003) Reading All Over the World: PIRLS National Report for England 2003 (Slough, National Foundation for Educational Research).

TYLER, R.W. (1949) Basic Principles of Curriculum and Instruction (Chicago \& London, University of Chicago Press).

VYGOTSKY, L. (1962) Thought and Language (Cambridge, Mass., MIT Press). 
WATERLAND, L. (1985) Read With Me (Stroud, Thimble Press).

WHITE, J. (1991) Changing Practice: A history of the National Writing Project (York, National Curriculum Council).

WOODHEAD, C. (1998) Academia gone to seed, New Statesman, 20.3.98.

WRAGG, E.C., WRAGG, C.M., HAYNES, G.S. \& CHAMBERLAIN, R.P. (1998)

Improving Literacy in the Primary School (London, Routledge).

WYSE, D. \& JONES, R. (2001) Teaching English, Language and Literacy (London, RoutledgeFalmer). 